\title{
Forecasting End of COVID - 19 in India Based on Time Series Analysis
}

\author{
B S Kambo \\ Former Deputy Director (Statistics) \\ Ministry of Labour \& Employment \\ Government of India, New Delhi
}

\author{
Dr.Kulwinder Kaur, \\ Former Assistant Professor, Hindu College \\ University of Delhi110007
}

\begin{abstract}
In this paper, the Box-Jenkins Autoregressive Integrated Moving Average (ARIMA) models for active and exponential smoothing HOLT for removed rates has been estimated using daily time series data from 1 st April to $14^{\text {th }}$ September 2020.The active and removed rates are computed from cumulative confirmed, active, recovered and deceased cases. It has been found that $\operatorname{ARIMA}(0,1,1)$ and Holt exponential smoothing Models are best fit for active and removed rates respectively. Normalized $\mathrm{BIC}$ is 0.577 and 0.898 for active and removed rates respectively and is minimum among all the six models considered. Lack of fit of models is tested by Ljung-BoX $Q$ statistic. The pvalue is 0.925 and 0.840 for active and removed rates respectively Since for both the rates p-value is greater than 0.05 , hence conclude that our model does not show a lack of fit. On the basis of our analysis, active rate will be nullified latest by 5 th January 2020, if everything goes best, as $P$ M of India has assured on eve of Independence Day that vaccine for corona will be available very soon. Otherwise by $9^{\text {th }}$ February 2021 if the past trend continued and in worst situation it will tends to zero on 26th March 2021. We expect the removed rates will reach 100 percent by $20^{\mathrm{TH}}$ October 2020 if everything goes best and by 5th January 2021 if the past trend continued. On the assumptions that Pandemic will come to an end when removed rate in the population tends to 100 percent and active rate to zero percent. Thus on the basis our analysis we expect that COVID - 19 Pandemic may come to end latest either by $9^{\text {th }}$ February 2021 or 26th March 2021 subject to condition that the social distance and safely measures remains vigilance to stabilize and control the pandemic and in achieving India's recovery from COVID-19.
\end{abstract}

Keywords:- Epidemic; COVID-19; ARIMA; Forecast; Pandemich.

\section{INTRODUCTION}

The paper aims to develop a model to find the likely date of end of Pandemic of Novel Corona virus COVID19 in India. Global warning was sparked by the outbreak of contagious person-to-person pneumonia caused by the excessive acute respiratory corona virus 2 syndrome (SARS-COV-2, also known as COVID-19). Droplets of saliva or nose discharge while an infected person is coughing or sneezing causes the spreads of The COVID- 19 virus. On March 11, 2020, COVID-19 has been declared as an infectious disease by World Health Organization (WHO) and its outbreak is a pandemic that is has extend over the more than 209 countries. The most affected countries by this virus are Italy, China, Australia, the USA Brazil and India are. The source of the virus is still not established, but the first person found to positive is from Wuhan, China. In India, the first case of COVID-19 was tested as positive on January 30 2020, in Kerala. Milan Batista (2020) predicted the total number of cases and peak time of the corona virus epidemic in China, South Korea, and the rest of the World by fitting Logistic.Throughout the world 32.1 million people world have been diagnosed with COVID 19 while more than 23.7 million have recovered and 0.98 million had died (Worldometer, September $24^{\text {th }} 2020$ ). On September $24^{\text {th, }} 2020$ the total no. of confirmed, active, recovered and deceased cases in our county are 5730184, 966342, 4671850 and 91173 respectively. Though the number of confirmed cases of Covid 19 are accelerating but recovery rate $(81.56 \%)$ which almost 10 percent higher than that of world recovery rate $(73.8 \%)$.On other hand death rate $(1.6 \%)$ which is almost half that of world (3.1 $\%)$.In this paper, We, in this paper, attempted to find (i) the trends of active and removed rates for next six months (ii) and attempts to predict the likely dates when pandemic will come to an end. The paper is planned as follows; (I) Introduction, (II) Review of literature, (III) Methodology \& Modeling, (IV) Sources of data, (V) Empirical Results and lastly (VI) the Conclusions. Auto-Regressive Integrated Moving Average (ARIMA) model has been used to forecast the trend of COVID-19 cases using SPSS. The finding will be helpful in proper planning health services.

\section{REVIEW OF LITERATURE}

Jinming Cao et.al (2020) established the dynamic models of the six chambers .Their study revealed that the cumulative diagnosis of pneumonia of COVID-19 in mainland China can reach 36,343 (February 8, 2020), and the number of basic regenerations can reach 4.01.Tania et al. (2020) published the research paper on Forecasting of COVID-19 to predict confirmed cases using ARIMA models in order to have more readiness in healthcare systems. Ribeiro et al. (2020) developed efficient shortterm forecasting models for forecasting the number of future cases by using an autoregressive integrated moving average (ARIMA), cubist regression (CUBIST), random forest (RF), ridge regression (RIDGE), support vector regression (SVR) and stacking-ensemble learning models for evaluating in the task of time series forecasting with one, three, and six-days ahead the COVID-19 cumulative confirmed cases in ten Brazilian states with a high daily 
incidence. Chakraborty (2020) also used a hybrid approach based on ARIMA and Wavelet-based forecasting model to generate short-term (ten days ahead) forecasts of the number of daily confirmed cases for Canada, France, India, South Korea, and the UK. Tyagi et.al (2020) predicted that the no of confirmed cases at all India level will be 75391 , 100052 and 124712 by end of May 20, middle of June and end of June 2020 respectively but the corresponding actual no of confirmed were observed to be 190648, 343070 and 585792 respectively. Thus their prediction does not seem to fit in the current situation. Tiwari et al. (2020) predicted that the peak of the cases for India would be attained between the third and fourth weeks of April 2020. This outbreak is predicted to be controlled around the end of May 2020. The total number of predicted confirmed cases of COVID-19 might reach around 68,978, and the number of deaths due to COVID-19 are predicted to be 1557 around April 25, 2020, in India. However, this prediction does not seem to fit in the current situation as we have observed around 26283 confirmed cases and 825 deaths by 25th April 2020. Khan Farhan Mohammad et.al (2020) have selected an ARIMA $(1,1,0)$ model on the data collected from 31st January 2020 to 25th March 2020. Their results showed an increasing trend in the actual and forecasted numbers of COVID-19 cases with approximately 1500 cases per day, based on available data as on 04th April 2020.Tinani et.al (June 2020) used ARIMA model to forecast the trend of COVID-19 cases in R programming. Kumar et.al. (2020) used BAILEY'S MODEL to described that COVID- 19 epidemic would end in mid September 2020 but paper does not support conclusion.

\section{METHODOLOGY}

There are several methods dealing with time series forecasting, the most relevant is Box-Jenkins (1976) methodology which is used in this study. It is discussed in several publications viz. Chatfild C (1996); Montgomery, D.C. (1976); Pankratz, A (1983); Salas, J.D et.al (1980) and Vandaele, W (1983).ARIMA, short for 'Auto-Regressive Integrated Moving Average' is a class of models explaining a given time series based on its past values, i.e., its own lags and the lagged forecast errors, so that equation can be used to forecast future values. An ARIMA model is characterized by 3 terms: p, d, q.

Where, $\mathrm{p}$ is the order of the AR term. $\mathrm{q}$ is the order of the MA term.

$\mathrm{d}$ is the number of differencing required to make the time series stationary.

Box and Jenkins give a methodology (Fig. 1) in time series analysis to find the best fit of time series to past values in order to make future forecasts. The methodology consists of four steps: 1) Model identification. 2) Estimation of model parameters. 3) Diagnostic checking for the identified model appropriateness for modeling and 4) Application of the model (i.e. forecasting). Autocorrelation Function (ACF) and the Partial Autocorrelation Function (PACF) are two important diagnostic tools used with time series analysis and forecasting. These functions calculate the statistical relationships between observations in a single data series with lag. The plot of ACF helps to take a decision as to many moving average terms are to be included in the model. The PACF plot is used to decide how many auto regressive terms are necessary to expose one or more of the time lags where high correlations appear, seasonality of the series, trend either in the mean level or in the variance of the series Al-Ansari et.al (2006).

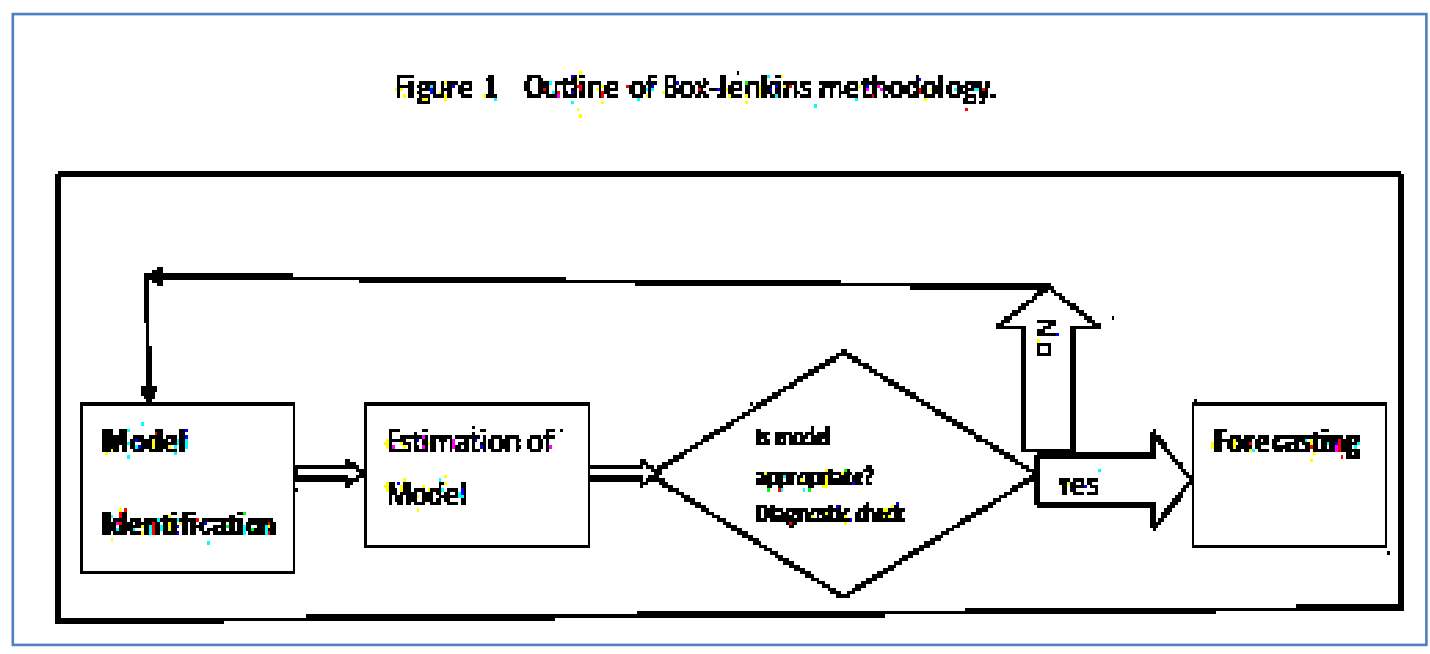

Fig 1 
ACF and PACF helps to identify provisional model (step 1). They are used not only to guess the form of the model, but also to obtain approximate estimates of the parameters Box G.E.P (1976).Method of Maximum likelihood that maximize the probability of observations is used to estimate the parameters in the model (step 2). The next, is checking on the adequacy of the model for the series (step 3). The assumption is that residual is a white noise process and that the process is stationary and independent. Model diagnostic checking is accomplished, in this work, through careful analysis of the residual series, the histogram of the residual, sample correlation and a diagnosis test Ljung (1978). Assumptions of model residuals are checked by Ljung-Box, Q-test. The best model among the class of models considered is one which has lowest BIC. Etebong. P (2014).

\section{Holt's Trend Corrected Exponential smoothing}

Holt exponential smoothing method is the most popular double exponential smoothing method, proposed by Holt (1957) with extending simple exponential smoothing to allow forecasting of data with a trend. Holt method is to concentrate on the series of increments $\mathrm{X}_{\mathrm{t}}-\mathrm{X}_{\mathrm{t}-1}$ and then estimate the slop parameter to a linear trend by exponential smoothing of these differences. The Holt method can be expressed as following formulas:

$$
\begin{aligned}
& \mathscr{X}_{t}=\alpha X_{t}+(1-\alpha)\left(\mathcal{X}_{t-1}+b_{t-1}\right) \text { and } \\
& b_{t}=\gamma\left(X_{t}-\not_{t-1}\right)+(1-\gamma) b_{t-1} .
\end{aligned}
$$

The formula for prediction is

$$
\hat{X}_{T+\mathrm{i}}=\hat{X}_{T}+\mathrm{i} b_{T} \text {. }
$$

In this formulation, two weighting parameter ( $\alpha$ and $\gamma)$ are used for the two updating equations.

In this study, daily Cumulative removed cases are computed as the sum of the cumulative of recovered and cumulative deceased cases. Active rate is computed as the percentage of cumulative active cases to the cumulative confirmed cases. Removed rate is computed as the percentage of cumulative removed cases to the cumulative confirmed cases. We are assuming that the pandemic will come to end when the active rate tends zero and the removed rate to approaching to $100 \%$. We explore suitable best fit ARIMA model to find the projection of active and removed rate.

\section{SOURCE OF DATA}

The daily data on Cumulative Confirmed, Active , Deceased and recovered cases from 1st April 2020 to 6th September 2020 was used in this study, and extracted from the Websites: www.covid19india.org . This Data is available in the public Domain.

\section{EMPIRICAL RESULTS}

We first checked whether the time series of Cumulative active and Cumulative removed rates of COVID - 19 cases are stationary or not. Figure 2 clearly revealed that non stationary is inherent in data as active and removed rate are showing downward and upward trends respectively.

\section{Daily Active and Removed Rates from Ist April to 14 th September 2020}

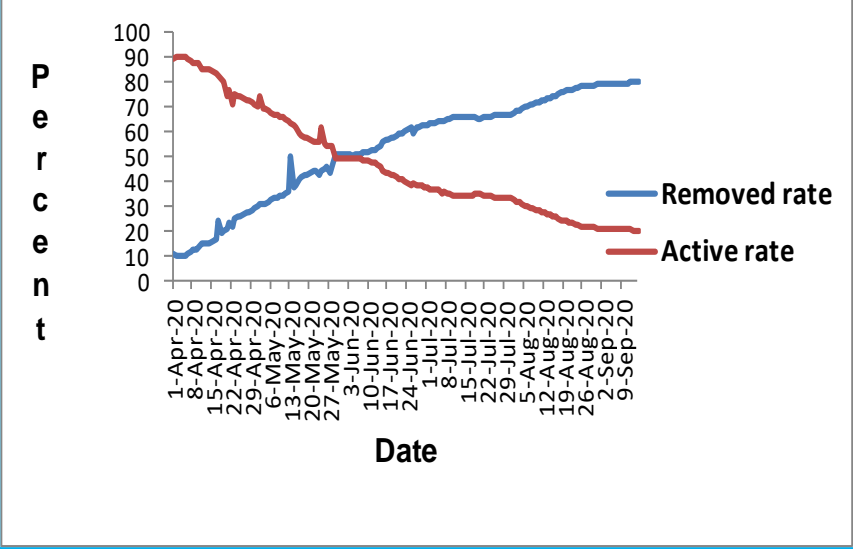

Fig 2

The times series of active and removed rates are transformed by taking non seasonal differences one and plots Autocorrelation Function (ACF) and Partially Autocorrelation Function (PAFC) of the transformed series figure 3 which clearly shows that the time series is stationary.

For the identification of the model, the task is to find out the appropriate values of $p$ and $q$ with the help of ACF and PACF graph values. The initial number of the ARIMA model was guessed through the ACF and PACF graphs. From a close examination of the ACF and PACF of active rate Fig 3(a) and Removed rate 3(b) of the first differenced series, we noticed that the ACF show significant peak at low lag 1 implying thereby that there may be at the most one non-seasonal moving average (MA) terms i.e. $\mathrm{q}=0$ or, 1 , and the corresponding PACF plot shows significant peak at low lag (1) indicating that there may be at the most one non seasonal autoregressive (AR) terms therefore $\mathrm{p}$ can takes the value either 0 or 1 . 


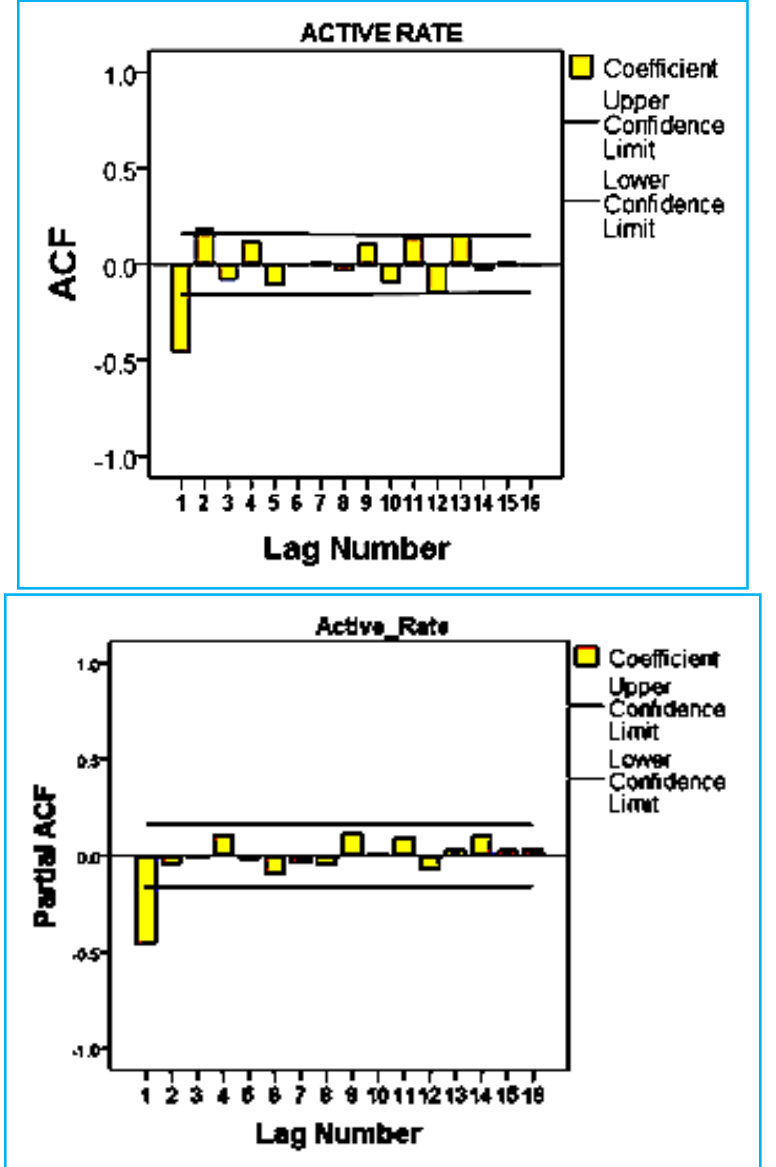

Fig 3(a):- Correlogram for the Active Rate of COVID-19 in India

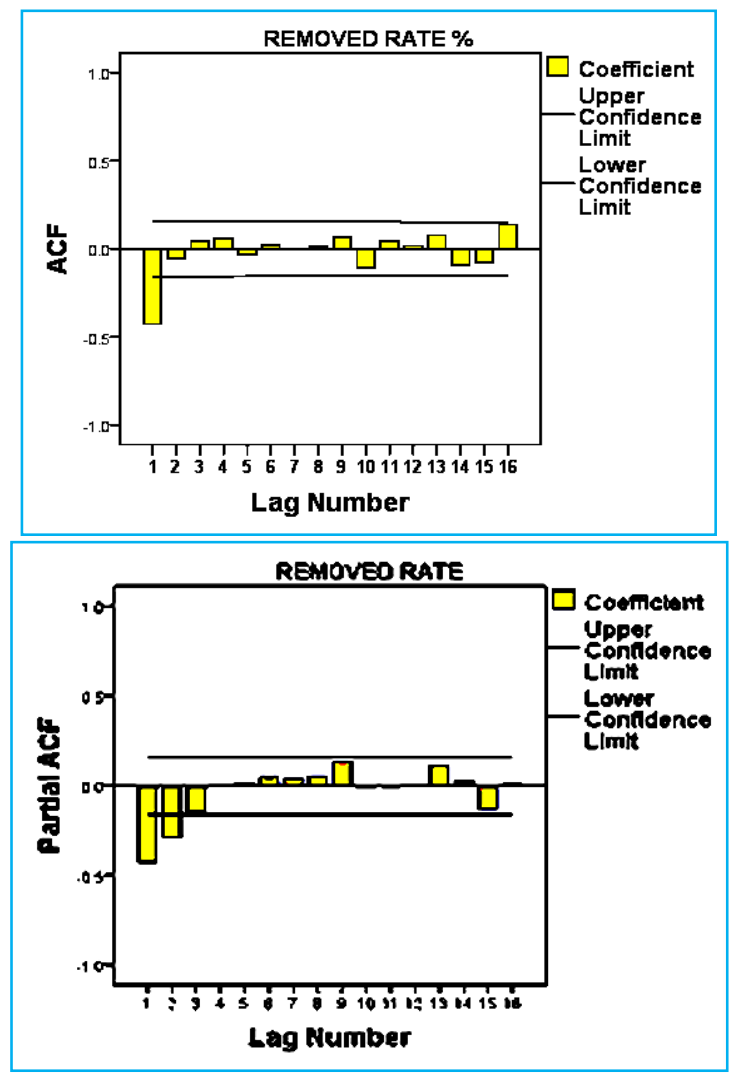

Fig 3(b):- Correlogram for the Removed Rate of COVID19 in India
This implies that the stochastic process can generate the modeling for active and removed rates with the following successful Models.

\section{Table 1 ARIMA MODELS WITH POSSIBLE VALUES OF BIC}

\begin{tabular}{|c|c|c|c|}
\hline ACTIVE RATE & BIC & REMOVED RATE & BIC \\
\hline ARIMA $(0,1,1)$ & 0.577 & $\begin{array}{c}\text { Simple exponential } \\
\text { smoothing }\end{array}$ & 1.104 \\
\hline ARIMA $(1,1,0)$ & 1.363 & $\begin{array}{c}\text { Simple exponential } \\
\text { smoothing with square } \\
\text { root transformation }\end{array}$ & 1.108 \\
\hline ARIMA ( $1,1,1)$ & 1.102 & Holt with no transformation & 0.898 \\
\hline ARIMA (1,1,2) & 1.137 & Brown & 0.909 \\
\hline ARIMA ( $0,2,1)$ & 1.203 & $\begin{array}{c}\text { Brown with squqre root } \\
\text { transformation }\end{array}$ & 0.921 \\
\hline ARIMA ( 1,2,0) & 1.554 & Damped trend & 0,925 \\
\hline
\end{tabular}

The most important measure of goodness of fit of model are statistics viz. $\mathrm{R}^{2}$, likelihood function (for maximum likelihood estimation), standard error of estimate and the $\mathrm{Q}$ statistic has been summarized in Table 2.For a well-fitted model, the $\mathrm{Q}$ statistic is expected to be statistically insignificant. Another important criterion for checking the adequacy of a fitted model is the Normalized Bayesian Information Criteria (BIC). When considering several ARIMA models we choose the one with the lowest BIC (TABLE 1).Based on these our important statistics and BIC. ARIMA (1, 1 0$)$ and HOLT exponential smoothing were found to be best fit for active and removed rates respectively. The $\mathrm{R}^{2}$ is an estimate of the proportion of the total variation in the series explained by the model. It has been found (Table 2) that the applied model for active and removed rates explains $99 \%$ of variation in data.

\begin{tabular}{|c|c|c|c|c|c|c|c|c|c|c|}
\hline \multicolumn{11}{|c|}{ Table 2 Model Statistic ARIMA } \\
\hline \multicolumn{11}{|c|}{ Model Statistics } \\
\hline \multirow[t]{2}{*}{ Rate } & \multirow[t]{2}{*}{ Model } & \multicolumn{5}{|c|}{ Model Fit statistics } & \multicolumn{3}{|c|}{ Ljung-Box Q(18) } & \multirow{2}{*}{$\begin{array}{c}\text { Numbe } \\
\text { of } \\
\text { Outlier }\end{array}$} \\
\hline & & \begin{tabular}{|c|} 
Stationary \\
$\mathrm{R}^{2}$
\end{tabular} & $R^{2}$ & RM SE & \begin{tabular}{|l|} 
MaxAE \\
\end{tabular} & $\begin{array}{c}\text { Normalized } \\
\text { BIC }\end{array}$ & Statistics & DF & Sig. & \\
\hline Active Rate & ARIMA $0,1,1$ & 0.196 & 0.996 & 1.294 & 7.003 & .577 & 8.641 & 17 & 0.925 & 0 \\
\hline \begin{tabular}{|l} 
Removed \\
Rate
\end{tabular} & Holt & 0.748 & 0.995 & 1.519 & 13.287 & .898 & 13.438 & 16 & 0.840 & 0 \\
\hline
\end{tabular}

Root Mean Square Error (RMSE) measure of how much a dependent series varies from its model-predicted level, expressed in the same units as the dependent series. Thus the variation of the original active and removed rates time series data from model-predicted level is 1.294 and1.51 respectively. The normalized BIC (Bayesian Information Criterion) measures the overall fit of a model that attempts to account for model complexity. Normalized BIC is 0.577 and 0.898 for active and removed rates respectively. The test the lack of fit of models is tested by Ljung-BoX Q statistic The null hypothesis, H0: The model does not show a lack of fit, Against the alternative hypothesis, H1: The model does show a lack of fit. Here, 
for active rates $\mathrm{p}$-value is 0.925 , for removed rate $\mathrm{p}$-value is 0.840 since for both the rates $\mathrm{p}$-value is greater than 0.05 , hence we do not reject the null hypothesis and conclude that our model does not show a lack of fit. The estimated coefficient of ARIMA $(1,1,0)$ and HOLT models are shown in the table 3.The parameter estimates of these Model are all significant $(\mathrm{p}<0.01)$.

Again, the models are adequate in the sense that the plots of the residual ACF and PACF for active and removed rates in figures 4 show a random variation, thus, from the origin zero (0), the points below and above are all uneven, hence the model fitted is adequate.

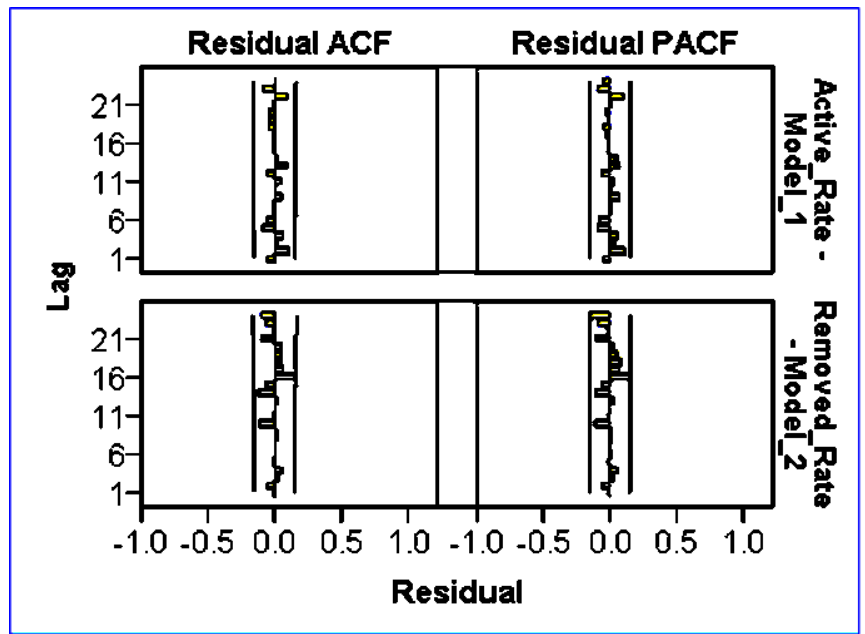

Fig 4:- Graph of the residual ACF and PACF for Active and Removed rates

The location parameter (mean) of the Noise residual for active rate is approximately zero 0.0004 with constant variance 0.0899 and the corresponding parameter (mean) of the Noise residual value for removed rate is -0.1278 with constant variance 1.5091 The normality test of the error (Noise Residual) conducted by drawing histogram of the residuals shown in figure Figures 5(a) and 5(b) suggests that the error distribution is approximately normal.

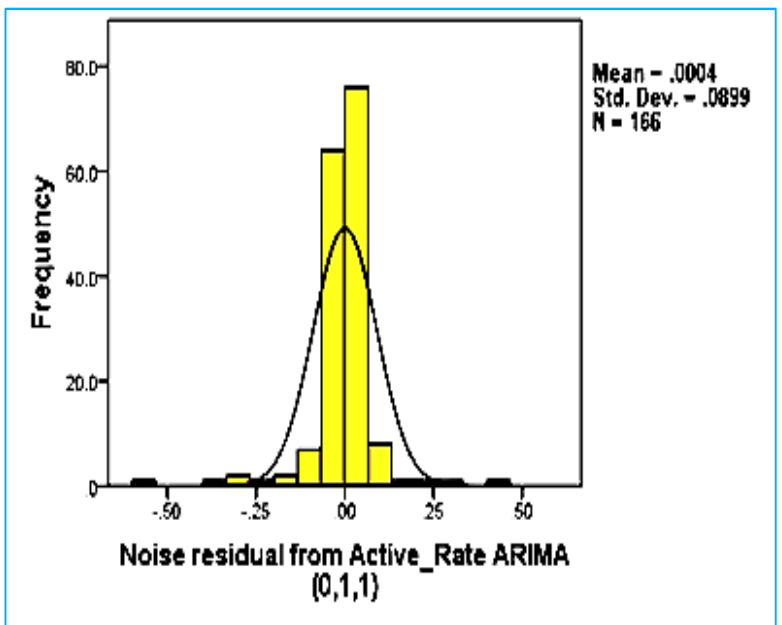

Fig 5(a):- Histogram of Noise Residual of Active Rate

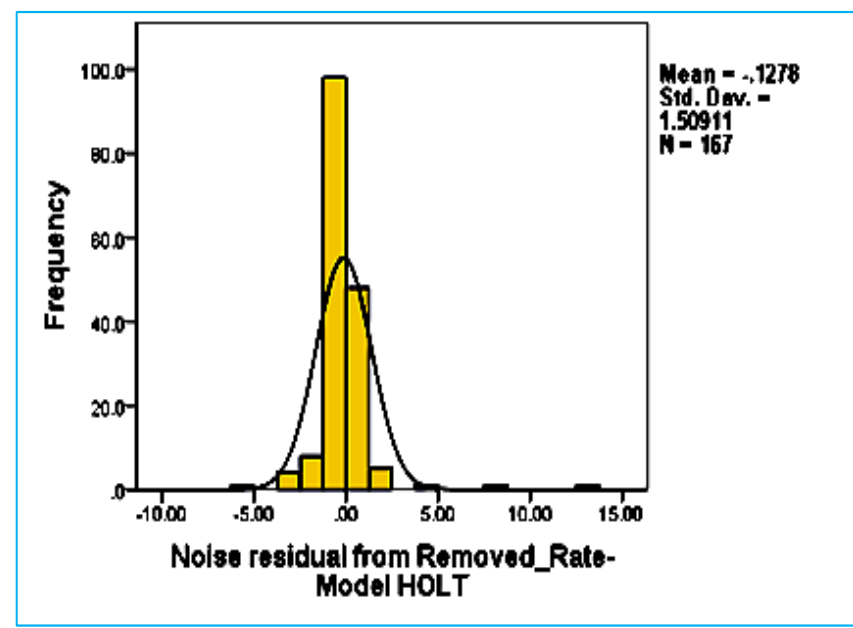

Fig 5(b):- Histogram of Noise Residual of Removed Rate

Therefore the assumptions of the error component in the ARIMA $(0,1,1)$ and HOLT Models are fulfilled and thus these model can forecast the future trend of the active and removed rates.

It has been found that date-wise estimated active and removed rates from 1st April 2020 to 14th September 2020 are very close to actual rates Figures 6 clearly indicates that Models are good fit to the data.

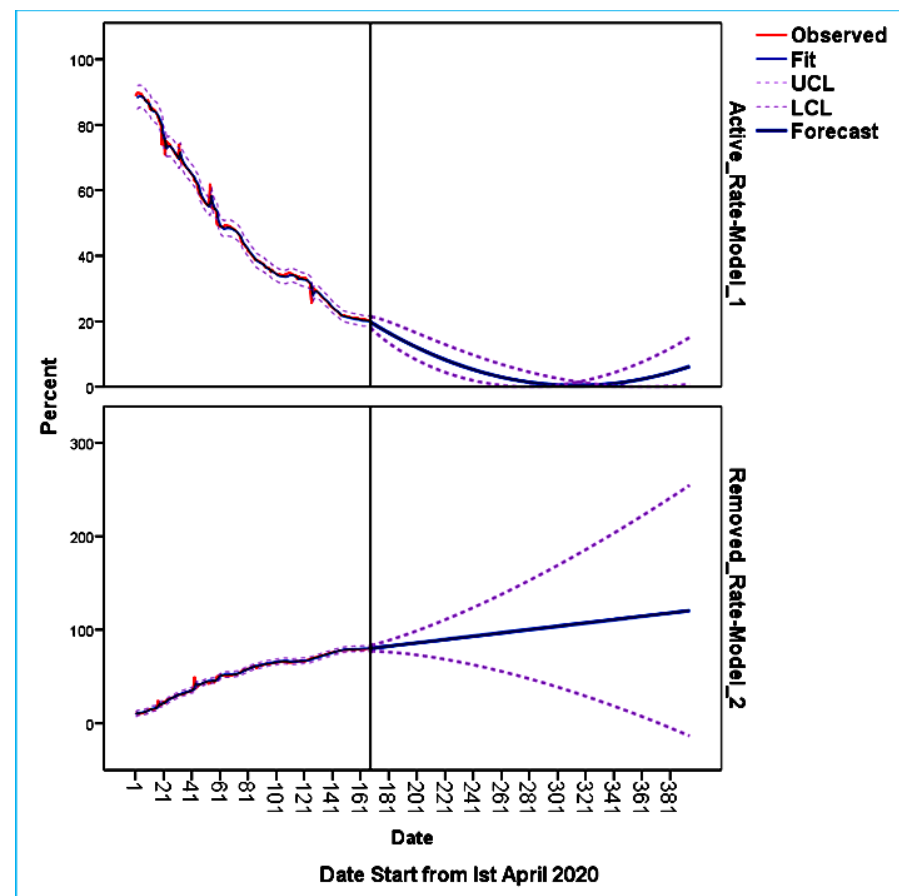

Fig 6:- Observed, Fit and Forecasted Active and Removed Rate

Following India's tireless fight against the swiftly sprouting COVID-19 pandemic since the past six months, the country finally sees signs of green shoots with the faster recoveries and sharp decline of active cases. The researchers around the world are making rigorous efforts to find effective vaccine and/or therapeutics against corona virus or SARS-CoV-2 diseases and the existence of such pharmaceutical interventions will extraordinarily change 
the results .Our analysis shows that following India's peak, daily active rate are projected to decline very steadily $(0.4)$ percent per day) from $88.33 \%$ from Ist April 2020 to 20.08
$\%$ in mid of $14 \mathrm{~h}$ September 2020 Figure 6 and Table 6 appendix.

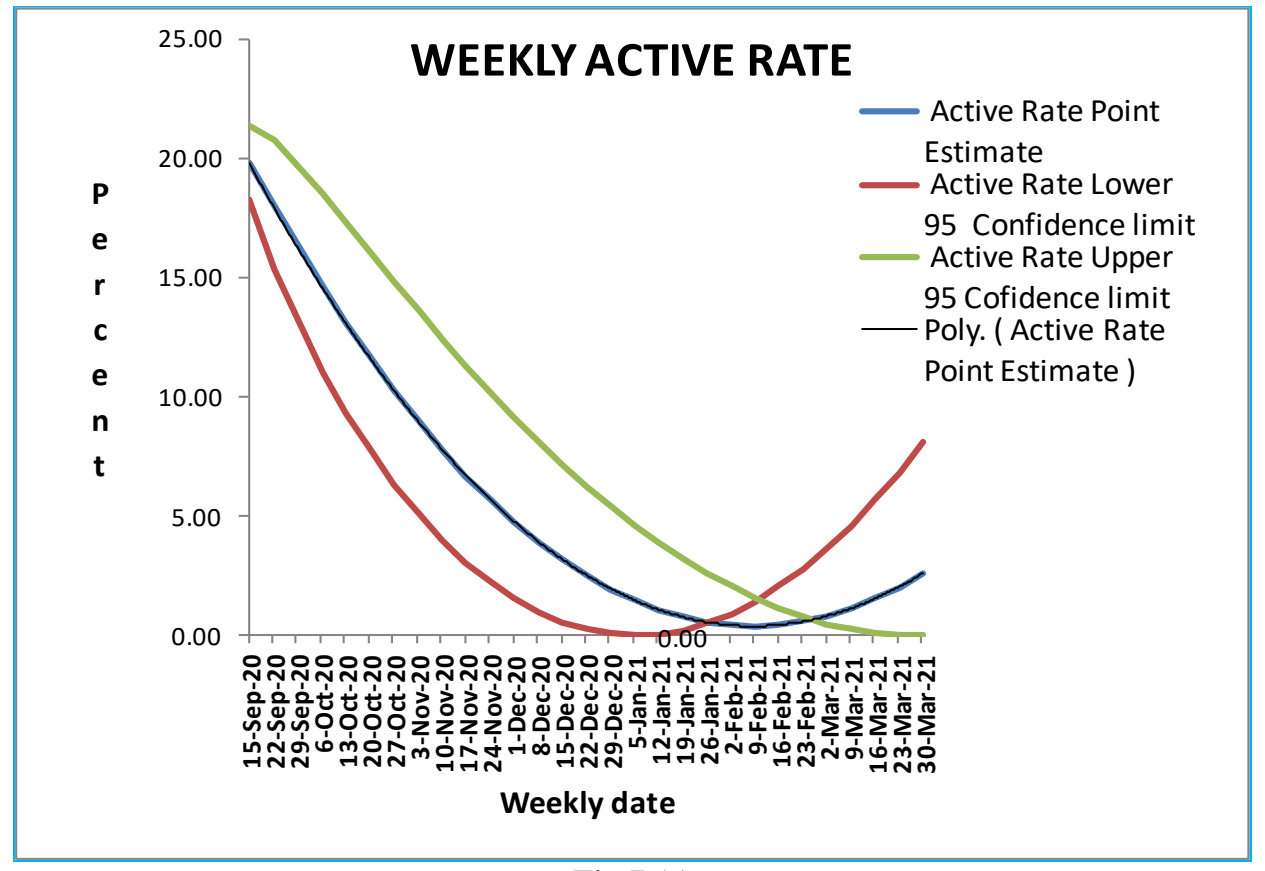

Fig 7 (a)

\begin{tabular}{|c|c|c|c|}
\hline \multirow[t]{2}{*}{ Date } & \multicolumn{3}{|c|}{$\begin{array}{l}\text { Active Rate } \\
\end{array}$} \\
\hline & $\begin{array}{l}\text { Point } \\
\text { Estimate }\end{array}$ & $\begin{array}{l}\text { Lower } 95 \\
\text { Confidence limit }\end{array}$ & \begin{tabular}{|} 
Upper 95 \\
Cofidence limit
\end{tabular} \\
\hline $15-\operatorname{Sep}-20$ & 19.77 & 18.21 & 21.3 \\
\hline $22-\operatorname{Sep} 20$ & 17.96 & 15.35 & 20.72 \\
\hline $6-0 \mathrm{ct}-20$ & 14.61 & 11.08 & 18.51 \\
\hline 13-0ct-20 & 13.08 & 9.29 & 17.2 \\
\hline $20-0 c t-20$ & 11.61 & 7.72 & 16.0 \\
\hline $27-0 \mathrm{ct}-20$ & 10.24 & 6.32 & 14.82 \\
\hline 3-Nor-20 & 8.98 & 5.08 & 13.61 \\
\hline $10-$ Nor 20 & 7.77 & 3.99 & 12 \\
\hline $17-$ Nor 20 & 6.67 & 3.04 & 11.2 \\
\hline $24-\mathrm{Nov}-20$ & 5.08 & 222 & 10.18 \\
\hline 1-Deo 20 & 4.74 & 1.54 & 9.12 \\
\hline 8-Deo 20 & 3.90 & 0.98 & 8. 10 \\
\hline 15-Dea 20 & 3.16 & 0.55 & \\
\hline 22-Deo 20 & 2.50 & 0.25 & 6.2 \\
\hline 29-Deo- 20 & 1.93 & 0.08 & 5.3 \\
\hline 5. Jan-21 & 1.45 & 0.00 & 4.59 \\
\hline 12- $\operatorname{san}-21$ & 1.08 & 0.05 & 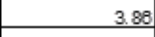 \\
\hline 19-Jan-21 & 0.78 & 0.22 & 3.1 \\
\hline 20. $\operatorname{Van}-21$ & 0.54 & 0.51 & 2.58 \\
\hline 2 -Feb-21 & 0.42 & 0.91 & 203 \\
\hline $9-\mathrm{Feb}-21$ & 0.38 & 1.42 & 1.54 \\
\hline 16 -Feb- 21 & 0.43 & 205 & 1. 12 \\
\hline 23-Feb-21 & 0.57 & 279 & 0.77 \\
\hline $2-M a r-21$ & 0.80 & 3.64 & 0.48 \\
\hline $9-M a-21$ & 1.12 & 4.59 & 0.28 \\
\hline $18-M a r-21$ & 1.53 & 5.86 & 0.1 \\
\hline 23-Mr-21 & 2.02 & 6.84 & 0.02 \\
\hline 30-Mar-21 & 2.80 & 8.13 & \\
\hline
\end{tabular}

Table 3:- Weekly Predicted Active Rates from 15th

September 2020 to 30 March 2021

It has been observed from Table 4 and figure 7(a) that the point estimate of active rate will further decline to 6.67 percent on 17 th November 2020 from 19.77 on 15 th
September 2020. Our estimates are matching with the Times Fact-India Outbreak Report (August 21) who projected daily active case counts are projected to decline by November 17. It expected to further falls rapidly to 1.45 percent on 5th January 2021 in a period of next one and half months. They are approaching to 0.38 percent on $9^{\text {th }}$ February 2021 thereafter it again start rising. However the lower and upper limits of the 95 percent confidence interval of active rates approaches to zero and zero percent respectively on $5^{\text {th }}$ January 2020 and 26th March 2021 .Thus we conclude on the basis of our analysis that active cases will be nullified latest by $5^{\text {th }}$ January 2020, if everything goes best, as P M of India has assured on eve of independence day that vaccine for corona will be available very soon,otherwise by $9^{\text {th }}$ February 2021 if the past trend continued and in worst situation an active cases will tends to zero on 26th March 202.

Our analysis shows that removed rates are accelerating steadily ( 0.42 percent per day) from 11 percent in 1st April 2020 to 79.91 percent on $14^{\text {th }}$ September 2020 (Figure 6 and Table 7 in the appendix) It has been found (Table $5 \&$ figure 7(b)) that the point estimate of removed rates will inclined to 91 percent on $17^{\text {th }}$ November 2020 from 80 on $15^{\text {th }}$ September 2020. It increased by 11 percentile point in a period of period of two months. Removed rates are expected to tend to 100 percent on 5th January 2021 in a period of next one and a half months. 


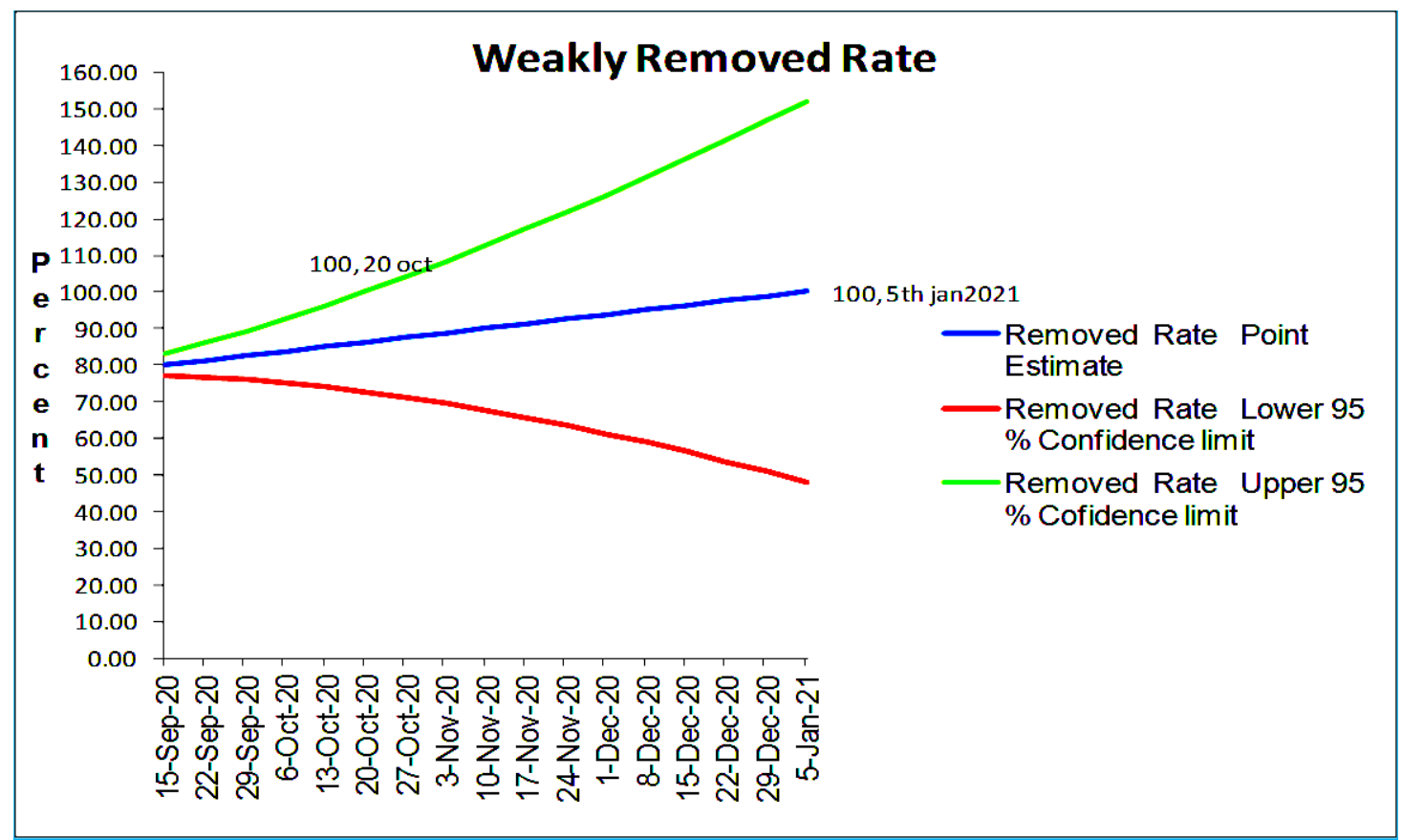

Fig 7 (b)

\begin{tabular}{|c|c|c|c|}
\hline \multirow[t]{2}{*}{ Date } & \multicolumn{3}{|c|}{ Removed Rate } \\
\hline & $\begin{array}{c}\text { Point } \\
\text { Estimate }\end{array}$ & $\begin{array}{c}\text { Lower } 95 \% \\
\text { Confidence limit }\end{array}$ & $\begin{array}{c}\text { Upper } 95 \% \\
\text { Cofidence limit }\end{array}$ \\
\hline $15-S e p-20$ & 80.15 & 77.15 & 83.15 \\
\hline $22-5$ ep -20 & 81.39 & 76.75 & 86.04 \\
\hline $29-S e p-20$ & 82.64 & 76.06 & 89.22 \\
\hline $6-0$ ct -20 & 83.88 & 75.12 & 92.64 \\
\hline $13-0$ ct -20 & 85.13 & 73.98 & 96.28 \\
\hline $20-0 \mathrm{ct}-20$ & 86.37 & 72.65 & 100.10 \\
\hline $27-0 \mathrm{ct}-20$ & 87.62 & 71.13 & 104.10 \\
\hline $3-\mathrm{N}$ ov -20 & 88.86 & 69.45 & 108.27 \\
\hline $3-\mathrm{N}$ ov -20 & 88.86 & 69.45 & 108.27 \\
\hline $10-\mathrm{N}$ ov -20 & 90.11 & 67.62 & 112.60 \\
\hline $17-\mathrm{N}$ ov- 20 & 91.35 & 65.63 & 117.07 \\
\hline $24-\mathrm{N}$ ov -20 & 92.60 & 63.50 & 121.69 \\
\hline 1-Dec-20 & 93.84 & 61.24 & 126.44 \\
\hline 8-Dec-20 & 95.09 & 58.85 & 131.32 \\
\hline 15-Dec-20 & 96.33 & 56.32 & 136.34 \\
\hline 22-Dec-20 & 97.57 & 53.68 & 141.47 \\
\hline 29-Dec-20 & 98.82 & 50.92 & 146.72 \\
\hline $5 \sqrt{ }$ an -21 & 100.06 & 48.04 & 152.09 \\
\hline
\end{tabular}

Table 4:- Weekly Predicted Removed Rate from 7th September to 9 th November 2020

Thus we expect that removed rates will be 100 by $5^{\text {th }}$ January 2021 if the past trend continued.

\section{CONCLUSION}

The world is going through a pandemic, and almost every country is affected by it. A country needs to know how much burden of active and confirmed cases it will have to bear in the coming time. We used ARIMA model on the time series data of COVID-19 cases in India for forecasting the active and removed rates till end of 31
March 2021. The future is always unpredictable and we must keep this in mind when we read any kind of predictions. Our model forecasts give the following two estimates of end dates: On the basis of our assumptions that Pandemic will come to an end when removed rate in the population tends to 100 percent and active rate approaches to zero.

Thus on the basis our analysis we expect that COVID - 19 Pandemic may come to end latest either by $9^{\text {th }}$ February 2021 or $26^{\text {th }}$ March 2021 subject to condition that the social distance and safely measures remains vigilance to stabilize and control the pandemic and in achieving India's recovery from COVID-19. The finding will be helpful in proper planning health services

\section{REFERENCES}

[1]. Batista M. (2020), Estimation of the final size of the COVID-19epidemic.MedRxiv.doi: 10(2020.02), 1620023606.

[2]. Chakraborty, T., \& Ghosh, I. (2020). Real-time forecasts and risk assessment of novel coronavirus (COVID-19) cases: A data-driven analysis. Chaos, solitons, and fractals, 135, 109850. Advance online publication.

https://doi.org/10.1016/j.chaos.2020.109850

[3]. Chatfild, C., the Analysis of Time Series-an introduction, 5th Edn. Chapman and Hall, UK, (1996).

[4]. http://Covid19 india.org/ portal, last access: 31st July 2020.

[5]. Farhan Mohammad Khan , Rajiv Gupta (2020): ARIMA and NAR based prediction model for time series analysis of COVID-19 cases in India; http://www.keaipublishing.com/en/journals/journalof-safety-science-and-resilience 
[6]. Holt, C. C. (1957). Forecasting Trends and Seasonal by Exponentially Weighted Averages,ONR Memorandum No. 52, Carnegie Institute of Technology, Pittsburgh, USA (published in International Journal of Forecasting 2004, 20, 5-13)

[7]. Jinming Cao (2020), Xia Jiang and Bin Zhao, Epidemic prediction of COVID-19. Journal of Biomedical Research \& Innovation Research | Vol 1 Iss 1

[8]. Kumar P., Kalita H., Patairiya S., Sharma Y. D., Nanda C., Rani M., Rahmai J., Bhagavathula A. S. (2020), Forecasting the dynamics of COVID-19 Pandemic in Top 15 countries in April 2020 through ARIMA Model with Machine Learning Approach. MedRxiv. https://doi.org/10.1101/2020.03.30.20046227

[9]. Kumar A, Roy R. Application of Mathematical Modeling in Public Health Decision MakingPertaining to Control of COVID-19 Pandemic in India. Epidem Int 2020; 5(2): 23-26.

[10]. Khimya Tinani, K. Muralidharan, Akash Deshmukh, Bhagyashree Patil, Tanvi Salat and Rajeshwari Rajodia ( May 2020), Analysis and Forecasting of COVID-19 Cases Across Hotspot States of India

[11]. Montgomery, D.C. and L.A. Johnson, Forecasting and Time Series Analysis. McGraw-Hill Book Company, http://www.abebooks.com/Forecasting-TimeSeriesAnalysis-Montgomery-Douglas/1323032148/bd, McGraw-Hill, (1976)

[12]. Pankratz, A., Forecasting With Univariate BoxJenkins Models Concepts and Cases. ISBN 0-471-
09023-9, pp: 414, John Wiley \& Sons, Inc. New York, USA, (1983)

[13]. Ribeiro, M.H.D.M., Da Silva, R.G., Mariani, V.C. and Coelho, L.S. (May, 2020). Short-term forecasting COVID-19 cumulative confirmed cases: Perspectives for Brazil. Chaos, Solitons and Fractals, 135, 110.alas, J.D., Delleur, J.W., Yevjevich, V., and Lane, W.L., Applied Modeling of Hydrologic Time series. ISBN13:978-0-918334-374, Water Resources Publication, Michigan, USA. (1980).

[14]. Statistical Package for Social Science (SPSS version 18) IBM.

[15]. Tania D., Mardani-Fard, H.A. and Paria, D. (March 2020). Forecasting of COVID-19

[16]. Times Fact-India Outbreak Report (21august 20)

[17]. Tandon, H., Ranjan, P., Chakraborty, T., \& Suhag, V. (2020). Coronavirus (COVID-19): ARIMA based time-series analysis to forecast near future. arXiv preprint arXiv: 2004.07859.

[18]. Tyagi Rishabh , Bramhankar1 Mahadev , Pandey1Mohit, Kishore M (2020) : COVID 19: Realtime Forecasts of Confirmed Cases, Active Cases, and Health Infrastructure Requirements for India and its Majorly Affected States using the ARIMA model. medRxiv. https://doi.org/10.1101/2020.05.17.20104588

[19]. Vandaele, W. (1983) Applied time series and BoxJenkins Models. Academic Press Inc, Orlando, Florida, ISBN: 10:0121126503 -417

[20]. World Population Prospects 2019 https://population.un.org/wpp/Publications/Files/WPP 2019_Highlights.pdf 
ISSN No:-2456-2165

\begin{tabular}{|c|c|c|c|c|c|c|c|c|c|c|c|c|c|c|c|}
\hline \multirow{3}{*}{ Date $L$} & \multirow{3}{*}{$\begin{array}{l}\text { Table } 5 \\
\begin{array}{c}\text { Point } \\
\text { Estimate }\end{array}\end{array}$} & \multicolumn{11}{|c|}{ Predicted Active Rates Rates with 95 percent confidence interval from 15th September 2020 t0 31st March 2021} & \multicolumn{3}{|c|}{ Appendix } \\
\hline & & \multicolumn{2}{|c|}{ Active Rates \% } & \multirow[t]{2}{*}{ Date } & \multicolumn{3}{|c|}{ Active Rates \% } & \multirow[t]{2}{*}{ Date } & \multicolumn{3}{|c|}{ Active Rates \% } & Date & & Active Rates $\%$ & \\
\hline & & \begin{tabular}{c|} 
Lower $95 \%$ \\
Confidence limit
\end{tabular} & $\begin{array}{c}\text { Upper } 95 \% \\
\text { Cofidence limit }\end{array}$ & & $\begin{array}{l}\text { Point } \\
\text { Estimate }\end{array}$ & \begin{tabular}{|c|} 
Lower $95 \%$ \\
Confidence limit
\end{tabular} & \begin{tabular}{|c|} 
Upper $95 \%$ \\
Cofidence limit
\end{tabular} & & \begin{tabular}{|c|} 
Point \\
Estimate
\end{tabular} & \begin{tabular}{|c|} 
Lower $95 \%$ \\
Confidence limit
\end{tabular} & $\begin{array}{c}\text { Upper } 95 \% \\
\text { Cofidence limit }\end{array}$ & & \begin{tabular}{|c|} 
Point \\
Estimate
\end{tabular} & \begin{tabular}{|c|} 
Lower $95 \%$ \\
Confidence limit
\end{tabular} & $\begin{array}{c}\text { Upper } 95 \% \\
\text { Cofidence limit }\end{array}$ \\
\hline 1-Sep-20 & & & & 1-Nov-20 & 9.32 & 5.42 & 13.95 & $1-\operatorname{Jan}-21$ & 1.72 & 0.02 & 5.04 & $1-$ Mar-21 & 0.76 & 3.51 & 0.52 \\
\hline 2-Sep-20 & & & & 2-Nov-20 & 9.14 & 5.25 & 13.78 & 2-Jan-21 & 1.65 & 0.01 & 4.93 & 2-Mar-21 & 0.80 & 3.64 & 0.48 \\
\hline 3-Sep-20 & & & & 3-Nov-20 & 8.96 & 5.08 & 13.61 & 3-Jan-21 & 1.58 & 0.01 & 4.81 & 3-Mar-21 & 0.84 & 3.77 & 0.44 \\
\hline 4-Sep-20 & & & & 4-Nov-2O & 8.79 & 4.92 & 13.44 & 4-Jan-21 & 1.51 & 0.01 & 4.70 & 4-Mar-21 & \begin{tabular}{l|}
0.88 \\
\end{tabular} & 3.90 & 0.41 \\
\hline 5-Sep-20 & & & & 5-Nov-20 & 8.61 & 4.75 & 13.27 & 5-Jan-21 & 1.45 & 0.00 & 4.59 & 5-Mar-21 & 0.93 & 4.03 & 0.38 \\
\hline 6-Sep-20 & & & & 6-Nov-20 & 8.44 & 4.59 & 13.10 & 6-Jan-21 & 1.39 & 0.00 & 4.48 & 6-Mar-21 & \begin{tabular}{l|}
0.97 \\
\end{tabular} & 4.17 & 0.35 \\
\hline 7-Sep-20 & & & & 7-Nov-20 & 8.27 & 4.44 & 12.93 & 7-Jan-21 & 1.33 & 0.00 & 4.38 & 7-Mar-21 & 1.02 & 4.31 & 0.31 \\
\hline 8-Sep-20 & & & & 8-Nov-20 & 8.10 & 4.28 & 12.76 & 8-Jan-21 & 1.27 & 0.01 & 4.27 & 8-Mar-21 & \begin{tabular}{l|}
1.07 \\
\end{tabular} & 4.45 & 0.29 \\
\hline 9-Sep-20 & & & & 9-Nov-20 & 7.94 & 4.13 & 12.60 & 9-Jan-21 & 1.22 & 0.02 & 4.17 & 9-Mar-21 & 1.12 & 4.59 & 0.26 \\
\hline 10-Sep-20 & & & & 10-Nov-20 & 7.77 & 3.99 & 12.43 & 10-Jan-21 & 1.16 & 0.03 & 4.06 & 10-Mar-21 & \begin{tabular}{l|}
1.17 \\
\end{tabular} & 4.74 & 0.23 \\
\hline 11-Sep-20 & & & & 11-Nov-20 & 7.61 & 3.84 & 12.26 & 11-Jan-21 & 1.11 & 0.04 & 3.96 & 11-Mar-21 & 1.23 & 4.89 & 0.21 \\
\hline 12-Sep-20 & & & & 12-Nov-20 & 7.45 & 3.70 & 12.10 & 12-Jan-21 & 1.06 & 0.05 & 3.86 & 12-Mar-21 & 1.28 & 5.04 & 0.18 \\
\hline 13-Sep-20 & & & & 13-Nov-20 & 7.29 & 3.56 & 11.93 & 13-Jan-21 & 1.01 & 0.07 & 3.76 & 13-Mar-21 & 1.34 & 5.19 & 0.16 \\
\hline 14-Sep-20 & & & & 14-Nov-20 & 7.13 & 3.43 & 11.77 & 14-Jan-21 & 0.96 & 0.09 & 3.66 & 14-Mar-21 & 1.40 & 5.35 & 0.14 \\
\hline 15-Sep-20 & 19.77 & 18.21 & 21.37 & 15-Nov-20 & 6.98 & 3.29 & 11.61 & 15-Jan-21 & 0.92 & 0.11 & 3.56 & 15-Mar-21 & 1.46 & 5.50 & 0.12 \\
\hline 16-Sep-20 & 19.50 & 17.74 & 21.34 & 16-Nov-20 & 6.83 & 3.16 & 11.44 & 16-Jan-21 & 0.88 & 0.14 & 3.47 & 16-Mar-21 & 1.53 & 5.66 & 0.10 \\
\hline 17-Sep-20 & 19.24 & 17.29 & 21.27 & 17-Nov-20 & 6.67 & 3.04 & 11.28 & 17-Jan-21 & 0.83 & 0.16 & 3.37 & 17-Mar-21 & 1.59 & 5.83 & 0.09 \\
\hline 18-Sep-20 & 18.98 & 16.87 & 21.18 & 18-Nov-20 & 6.52 & 2.91 & 11.12 & 18-Jan-21 & 0.80 & 0.19 & 3.28 & 18-Mar-21 & 1.66 & 5.99 & 0.07 \\
\hline 19-Sep-20 & 18.72 & 16.47 & 21.08 & 19-Nov-20 & 6.38 & 2.79 & 10.96 & 19-Jan-21 & 0.76 & 0.22 & 3.19 & 19-Mar-21 & 1.73 & 6.16 & 0.06 \\
\hline 20 -Sep-20 & 18.47 & 16.08 & 20.97 & 20-Nov-20 & 6.23 & 2.67 & 10.80 & 20-Jan-21 & 0.72 & 0.26 & 3.10 & 20-Mar-21 & 1.80 & 6.32 & 0.05 \\
\hline 21-Sep-20 & 18.21 & 15.71 & 20.85 & 21-Nov-20 & 6.08 & 2.55 & 10.64 & 21-Jan-21 & 0.69 & 0.29 & 3.01 & 21-Mar-21 & 1.87 & 6.49 & 0.04 \\
\hline 22-Sep-20 & 17.96 & 15.35 & 20.72 & 22-Nov-20 & 5.94 & 2.44 & 10.49 & 22-Jan-21 & 0.65 & 0.33 & 2.92 & 22-Mar-21 & 1.94 & 6.67 & 0.03 \\
\hline $23-$ Sep-20 & 17.71 & 14.99 & 20.59 & 23-Nov-20 & 5.80 & 2.33 & 10.33 & 23-Jan-21 & 0.62 & 0.37 & 2.83 & 23-Mar-21 & 2.02 & 6.84 & 0.02 \\
\hline 24-Sep-20 & 17.46 & 14.65 & 20.45 & 24-Nov-20 & 5.66 & 2.22 & 10.18 & 24-Jan-21 & 0.60 & 0.42 & 2.74 & 24-Mar-21 & 2.10 & 7.02 & 0.01 \\
\hline $25-$ Sep-20 & 17.21 & 14.32 & 20.30 & $25-$ Nov-20 & 5.52 & 2.12 & 10.02 & 25-Jan-21 & 0.57 & 0.46 & 2.66 & 25-Mar-21 & 2.18 & 7.20 & 0.01 \\
\hline $26-$ Sep-20 & 16.96 & 13.99 & 20.15 & 26-Nov-20 & 5.39 & 2.01 & 9.87 & 26-Jan-21 & 0.54 & 0.51 & 2.58 & 26-Mar-21 & 2.26 & 7.38 & 0.00 \\
\hline 27-Sep-20 & 16.72 & 13.67 & 20.00 & 27-Nov-20 & 5.25 & 1.91 & 9.72 & 27-Jan-21 & 0.52 & 0.56 & 2.49 & 27-Mar-21 & 2.34 & 7.56 & 0.00 \\
\hline 28-Sep-20 & 16.48 & 13.35 & 19.84 & 28-Nov-20 & 5.12 & 1.81 & 9.56 & 28-Jan-21 & 0.50 & 0.61 & 2.41 & 28-Mar-21 & 2.43 & 7.75 & 0.00 \\
\hline 29 -Sep-20 & 16.24 & 13.05 & 19.68 & 29 -Nov-20 & 4.99 & 1.72 & 9.41 & 29-Jan-21 & 0.48 & 0.67 & 2.33 & 29-Mar-21 & 2.52 & 7.94 & 0.00 \\
\hline 30-Sep-20 & 16.00 & 12.75 & 19.52 & 30-Nov-20 & 4.86 & 1.63 & 9.26 & 30-Jan-21 & 0.46 & 0.72 & 2.25 & 30-Mar-21 & 2.60 & 8.13 & 0.00 \\
\hline $1-0 \mathrm{ct}-20$ & 15.76 & 12.45 & 19.36 & 1-Dec-20 & 4.74 & 1.54 & 9.12 & 31-Jan-21 & 0.44 & 0.78 & 2.18 & 31-Mar-21 & 2.69 & 8.32 & 0.01 \\
\hline $2-0 \mathrm{ct}-20$ & 15.53 & 12.16 & 19.19 & 2-Dec-20 & 4.61 & 1.45 & 8.97 & 1-Feb-21 & 0.43 & 0.85 & 2.10 & & & & \\
\hline 3-0ct-20 & 15.29 & 11.88 & 19.02 & 3-Dec-20 & 4.49 & 1.37 & 8.82 & 2-Feb-21 & 0.42 & 0.91 & 2.03 & & & & \\
\hline $4-0 c t-20$ & 15.06 & 11.60 & 18.85 & 4-Dec-20 & 4.37 & 1.28 & 8.68 & 3-Feb-21 & 0.41 & 0.98 & 1.95 & & & & \\
\hline $5-0 c t-20$ & 14.83 & 11.33 & 18.68 & 5-Dec-20 & 4.25 & 1.21 & 8.53 & 4-Feb-21 & 0.40 & 1.04 & 1.88 & & & & \\
\hline 6-0ct-20 & 14.61 & 11.06 & 6.00 & 6-Dec-20 & 4.13 & 1.13 & 8.39 & 5-Feb-21 & 0.39 & 1.12 & 1.81 & & & & \\
\hline 7-0ct-20 & 14.38 & 10.79 & 18.34 & 7-Dec-20 & 4.02 & 1.05 & 8.24 & 6-Feb-21 & 0.39 & 1.19 & 1.74 & & & & \\
\hline 8-0ct-20 & 14.16 & 10.53 & 18.17 & 8-Dec-20 & 3.90 & 0.98 & 8.10 & 7-Feb-21 & 0.39 & 1.26 & 1.67 & & & & \\
\hline 9-0ct-20 & 13.93 & 10.27 & 17.99 & 9-Dec-20 & 3.79 & 0.91 & 7.96 & 8-Feb-21 & 0.39 & 1.34 & 1.61 & & & & \\
\hline 10-0ct-20 & 13.71 & 10.02 & 17.82 & $10-D e c-20$ & 3.68 & 0.85 & 7.82 & 9-Feb-21 & 0.38 & 1.42 & 1.54 & & & & \\
\hline 11-Oct-20 & 13.49 & 9.78 & 17.64 & 11-Dec-20 & 3.57 & 0.78 & 7.69 & 10-Feb-21 & 0.38 & 1.51 & 1.48 & & & & \\
\hline 12-0ct-20 & 13.28 & 9.53 & 17.47 & 12-Dec-20 & 3.47 & 0.72 & 7.55 & 11-Feb-21 & 0.39 & 1.59 & 1.42 & & & & \\
\hline 13-0ct-20 & 13.06 & 9.29 & 17.29 & 13-Dec-20 & 3.36 & 0.66 & 7.41 & 12-Feb-21 & 0.39 & 1.68 & 1.35 & & & & \\
\hline 14-0ct-20 & 12.85 & 9.06 & 17.11 & 14-Dec-20 & 3.26 & 0.61 & 7.28 & 13-Feb-21 & 0.40 & 1.77 & 1.29 & & & & \\
\hline $15-0 \mathrm{ct}-20$ & 12.64 & 8.82 & 16.94 & $15-\mathrm{Dec}-20$ & 3.16 & 0.55 & 7.14 & 14-Feb-21 & 0.41 & 1.86 & 1.24 & & & & \\
\hline $16-0 \mathrm{ct}-20$ & 12.43 & 8.60 & 16.76 & 16-Dec-20 & 3.06 & 0.50 & 7.01 & 15-Feb-21 & 0.42 & 1.95 & 1.18 & & & & \\
\hline $17-0 c t-20$ & 12.22 & 8.37 & 16.58 & 17-Dec-20 & 2.96 & 0.45 & 6.88 & 16-Feb-21 & 0.43 & 2.05 & 1.12 & & & & \\
\hline 18-0ct-20 & 12.01 & 8.15 & 16.41 & 18-Dec-20 & 2.87 & 0.41 & 6.75 & 17-Feb-21 & 0.45 & 2.15 & 1.07 & & & & \\
\hline 19-0ct-20 & 11.81 & 7.93 & 16.23 & 19-Dec-20 & 2.77 & 0.36 & 6.62 & 18-Feb-21 & 0.46 & 2.25 & 1.01 & & & & \\
\hline $20-0$ ct-20 & 11.61 & 7.72 & 16.05 & 20-Dec-20 & 2.68 & 0.32 & 6.49 & 19-Feb-21 & 0.48 & 2.35 & 0.96 & & & & \\
\hline $21-0 \mathrm{ct}-20$ & 11.41 & 7.51 & 15.88 & 21-Dec-20 & 2.59 & 0.28 & 6.36 & 20-Feb-21 & 0.50 & 2.46 & 0.91 & & & & \\
\hline $22-0 \mathrm{ct}-20$ & 11.21 & 7.30 & 15.70 & 22-Dec-20 & 2.50 & 0.25 & 6.24 & 21-Feb-21 & 0.52 & 2.56 & 0.86 & & & & \\
\hline $23-0 \mathrm{ct}-20$ & 11.01 & 7.10 & 15.52 & 23-Dec-20 & 2.41 & 0.22 & 6.11 & 22-Feb-21 & 0.55 & 2.67 & 0.81 & & & & \\
\hline 24-0ct-20 & 10.82 & 6.90 & 15.35 & 24-Dec-20 & 2.33 & 0.18 & 5.99 & 23-Feb-21 & 0.57 & 2.79 & 0.77 & & & & \\
\hline $25-0 \mathrm{ct}-20$ & 10.62 & 6.71 & 15.17 & 25-Dec-20 & 2.25 & 0.16 & 5.87 & 24-Feb-21 & 0.60 & 2.90 & 0.72 & & & & \\
\hline $26-0 c t-20$ & 10.43 & 6.51 & 15.00 & 26 -Dec-20 & 2.16 & 0.13 & 5.74 & $25-\mathrm{Feb}-21$ & 0.63 & 3.02 & 0.68 & & & & \\
\hline $27-0 \mathrm{ct}-20$ & 10.24 & 6.32 & 14.82 & 27-Dec-20 & 2.09 & 0.11 & 5.62 & 26-Feb-21 & 0.66 & 3.14 & 0.64 & & & & \\
\hline $28-0 c t-20$ & 10.05 & 6.14 & 14.65 & 28-Dec-20 & 2.01 & 0.08 & 5.50 & $27-\mathrm{Feb}-21$ & 0.69 & 3.26 & 0.60 & & & & \\
\hline $29-0 c t-20$ & 9.87 & 5.95 & 14.47 & 29-Dec-20 & 1.93 & 0.06 & 5.39 & 28-Feb-21 & 0.73 & 3.38 & 0.56 & & & & \\
\hline $30-0$ ct-20 & 9.68 & 5.77 & 14.30 & $30-D e c-20$ & 1.86 & 0.05 & 5.27 & & & & & & & & \\
\hline $31-0$ ct-20 & 9.50 & 5.59 & 14.13 & 31-Dec-20 & 1.79 & 0.03 & 5.15 & & & & & & & & \\
\hline
\end{tabular}


ISSN No:-2456-2165

\begin{tabular}{|c|c|c|c|c|c|c|c|c|c|c|c|}
\hline \multirow{3}{*}{$\frac{\text { Table } 6}{\text { Date }}$} & \multicolumn{11}{|c|}{ Predicted Removed Rates Rates with 95 percent confidence interval from 15th September 2020 to 31 st January 2021} \\
\hline & \multicolumn{3}{|c|}{ Active Rates \% } & \multirow[t]{2}{*}{ Date } & \multicolumn{3}{|c|}{ Active Rates \% } & \multirow[t]{2}{*}{ Date } & \multicolumn{3}{|c|}{ Active Rates \% } \\
\hline & $\begin{array}{c}\text { Point } \\
\text { Estimate }\end{array}$ & \begin{tabular}{c|} 
Lower $95 \%$ \\
Confidence limit
\end{tabular} & $\begin{array}{c}\text { Upper } 95 \% \\
\text { Cofidence limit }\end{array}$ & & $\begin{array}{c}\text { Point } \\
\text { Estimate }\end{array}$ & \begin{tabular}{c|} 
Lower $95 \%$ \\
Confidence limit
\end{tabular} & \begin{tabular}{|c|} 
Upper $95 \%$ \\
Cofidence limit
\end{tabular} & & \begin{tabular}{|c|} 
Point \\
Estimate
\end{tabular} & \begin{tabular}{|c|} 
Lower $95 \%$ \\
Confidence limit
\end{tabular} & $\begin{array}{c}\text { Upper } 95 \% \\
\text { Cofidence limit }\end{array}$ \\
\hline 1-Sep-20 & & & & 1-Nov-20 & 88.51 & 69.95 & 107.06 & 1-Jan-21 & 99.35 & 49.70 & 149.01 \\
\hline 2-Sep-20 & & & & 2-Nov-20 & 88.68 & 69.70 & 107.67 & 2-Jan-21 & 99.53 & 49.29 & 149.77 \\
\hline 3-Sep-20 & & & & 3-Nov-20 & 88.86 & 69.45 & 108.27 & 3-Jan-21 & 99.71 & 48.87 & 150.54 \\
\hline 4-Sep-20 & & & & 4-Nov-20 & 89.04 & 69.20 & 108.88 & 4-Jan-21 & 99.89 & 48.46 & 151.32 \\
\hline 5-Sep-20 & & & & $5-$ Nov-20 & 89.22 & 68.94 & 109.49 & 5-Jan-21 & 100.06 & 48.04 & 152.09 \\
\hline 6-Sep-20 & & & & 6-Nov-20 & 89.40 & 68.68 & 110.11 & 6-Jan-21 & 100.24 & 47.62 & 152.86 \\
\hline 7-Sep-20 & & & & 7-Nov-20 & 89.57 & 68.42 & 110.72 & 7-Jan-21 & 100.42 & 47.19 & 153.64 \\
\hline 8-Sep-20 & & & & $8-\mathrm{Nov}-20$ & 89.75 & 68.16 & 111.35 & 8-Jan-21 & 100.60 & 46.77 & 154.42 \\
\hline 9-Sep-20 & & & & 9-Nov-20 & 89.93 & 67.89 & 111.97 & 9-Jan-21 & 100.77 & 46.34 & 155.21 \\
\hline 10-Sep-20 & & & & 10-Nov-20 & 90.11 & 67.62 & 112.60 & 10-Jan-21 & 100.95 & 45.91 & 155.99 \\
\hline 11-Sep-20 & & & & $11-$ Nov-20 & 90.28 & 67.34 & 113.23 & 11-Jan-21 & 101.13 & 45.48 & 156.78 \\
\hline 12-Sep-20 & & & & 12-Nov-20 & 90.46 & 67.06 & 113.86 & 12-Jan-21 & 101.31 & 45.05 & 157.57 \\
\hline 13-Sep-20 & & & & \begin{tabular}{|l|}
$13-N o v-20$ \\
\end{tabular} & 90.64 & 66.78 & 114.50 & 13-Jan-21 & 101.49 & 44.61 & 158.36 \\
\hline 14-Sep-20 & & & & 14-Nov-20 & 90.82 & 66.50 & 115.14 & 14-Jan-21 & 101.66 & 44.17 & 159.15 \\
\hline 15-Sep-20 & 80.15 & 77.15 & 83.15 & 15-Nov-20 & 91.00 & 66.21 & 115.78 & 15-Jan-21 & 101.84 & 43.73 & 159.95 \\
\hline 16-Sep-20 & 80.33 & 77.11 & 83.54 & 16-Nov-20 & 91.17 & 65.92 & 116.42 & 16-Jan-21 & \begin{tabular}{|l|}
102.02 \\
\end{tabular} & 43.29 & 160.75 \\
\hline 17-Sep-20 & 80.51 & 77.07 & 83.94 & 17-Nov-20 & 91.35 & 65.63 & 117.07 & 17-Jan-21 & 102.20 & 42.84 & 161.55 \\
\hline 18-Sep-20 & 80.68 & 77.02 & 84.35 & 18-Nov-20 & 91.53 & 65.34 & 117.72 & 18-Jan-21 & 102.37 & 42.40 & 162.35 \\
\hline 19-Sep-20 & 80.86 & 76.96 & 84.76 & 19-Nov-20 & 91.71 & 65.04 & 118.38 & 19-Jan-21 & 102.55 & 41.95 & 163.16 \\
\hline 20-Sep-20 & 81.04 & 76.90 & 85.18 & 20-Nov-20 & 91.88 & 64.74 & 119.03 & 20-Jan-21 & 102.73 & 41.50 & 163.96 \\
\hline 21-Sep-20 & 81.22 & 76.82 & 85.61 & $21-$ Nov-20 & 92.06 & 64.43 & 119.69 & 21-Jan-21 & 102.91 & 41.04 & 164.77 \\
\hline 22-Sep-20 & 81.39 & 76.75 & 86.04 & 22-Nov-20 & 92.24 & 64.13 & 120.35 & 22-Jan-21 & 103.09 & 40.59 & 165.59 \\
\hline 23-Sep-20 & 81.57 & 76.66 & 86.48 & 23-Nov-20 & 92.42 & 63.82 & 121.02 & 23-Jan-21 & 103.26 & 40.13 & 166.40 \\
\hline 24-Sep-20 & 81.75 & 76.58 & 86.92 & 24-Nov-20 & 92.60 & 63.50 & 121.69 & 24-Jan-21 & 103.44 & 39.67 & 167.21 \\
\hline 25-Sep-20 & 81.93 & 76.48 & 87.37 & 25-Nov-20 & 92.77 & 63.19 & 122.36 & 25-Jan-21 & 103.62 & 39.21 & 168.03 \\
\hline 26-Sep-20 & 82.11 & 76.38 & 87.83 & 26-Nov-20 & 92.95 & 62.87 & 123.03 & 26-Jan-21 & 103.80 & 38.74 & 168.85 \\
\hline 27-Sep-20 & 82.28 & 76.28 & 88.29 & $27-$ Nov-20 & 93.13 & 62.55 & 123.71 & 27-Jan-21 & \begin{tabular}{l|}
103.97 \\
\end{tabular} & 38.27 & 169.68 \\
\hline 28-Sep-20 & 82.46 & 76.17 & 88.75 & 28-Nov-20 & 93.31 & 62.23 & 124.39 & 28-Jan-21 & 104.15 & 37.81 & 170.50 \\
\hline 29-Sep-20 & 82.64 & 76.06 & 89.22 & 29-Nov-20 & 93.48 & 61.90 & 125.07 & 29-Jan-21 & \begin{tabular}{|l|}
104.33 \\
\end{tabular} & 37.34 & 171.33 \\
\hline 30-Sep-20 & 82.82 & 75.94 & 89.70 & $30-$ Nov-20 & 93.66 & 61.57 & 125.75 & 30-Jan-21 & 104.51 & 36.86 & 172.15 \\
\hline 1-Oct-20 & 82.99 & 75.81 & 90.18 & 1-Dec-20 & 93.84 & 61.24 & 126.44 & 31-Jan-21 & 104.69 & 36.39 & 172.98 \\
\hline 2-Oct-20 & 83.17 & 75.68 & 90.66 & 2-Dec-20 & 94.02 & 60.91 & 127.13 & & & & \\
\hline 3-Oct-20 & 83.35 & 75.55 & 91.15 & 3-Dec-20 & 94.20 & 60.57 & 127.82 & & & & \\
\hline 4 4-Oct-20 & 83.53 & 75.41 & 91.64 & 4-Dec-20 & 94.37 & 60.23 & 128.52 & & & & \\
\hline 5-Oct-20 & 83.71 & 75.27 & 92.14 & 5-Dec-20 & 94.55 & 59.89 & 129.22 & & & & \\
\hline 6-Oct-20 & 83.88 & 75.12 & 92.64 & 6-Dec-20 & 94.73 & 59.54 & 129.92 & & & & \\
\hline 7-Oct-20 & 84.06 & 74.97 & 93.15 & 7-Dec-20 & 94.91 & 59.20 & 130.62 & & & & \\
\hline 8-Oct-20 & 84.24 & 74.82 & 93.66 & 8-Dec-20 & 95.09 & 58.85 & 131.32 & & & & \\
\hline 9-Oct-20 & 84.42 & 74.66 & 94.18 & 9-Dec-20 & 95.26 & 58.49 & 132.03 & & & & \\
\hline $10-$ Oct-20 & 84.59 & 74.49 & 94.70 & 10-Dec-20 & 95.44 & 58.14 & 132.74 & & & & \\
\hline $11-$ Oct-20 & 84.77 & 74.33 & 95.22 & 11-Dec-20 & 95.62 & 57.78 & 133.46 & & & & \\
\hline 12-Oct-20 & 84.95 & 74.16 & 95.75 & 12-Dec-20 & 95.80 & 57.42 & 134.17 & & & & \\
\hline 13-Oct-20 & 85.13 & 73.98 & 96.28 & 13-Dec-20 & 95.97 & 57.06 & 134.89 & & & & \\
\hline 14-Oct-20 & 85.31 & 73.80 & 96.81 & 14-Dec-20 & 96.15 & 56.69 & 135.61 & & & & \\
\hline 15-Oct-20 & 85.48 & 73.62 & 97.35 & 15-Dec-20 & 96.33 & 56.32 & 136.34 & & & & \\
\hline $16-$ Oct-20 & 85.66 & 73.43 & 97.89 & 16-Dec-20 & 96.51 & 55.95 & 137.06 & & & & \\
\hline 17-Oct-20 & 85.84 & 73.24 & 98.44 & 17-Dec-20 & 96.69 & 55.58 & 137.79 & & & & \\
\hline $18-$ Oct-20 & 86.02 & 73.05 & 98.99 & 18-Dec-20 & 96.86 & 55.20 & 138.52 & & & & \\
\hline 19-Oct-20 & 86.20 & 72.85 & 99.54 & 19-Dec-20 & 97.04 & 54.83 & 139.25 & & & & \\
\hline $20-$ Oct-20 & 86.37 & 72.65 & 100.10 & 20-Dec-20 & 97.22 & 54.45 & 139.99 & & & & \\
\hline $21-$ Oct-20 & 86.55 & 72.44 & 100.66 & 21-Dec-20 & 97.40 & 54.06 & 140.73 & & & & \\
\hline $22-$ Oct-20 & 86.73 & 72.23 & 101.23 & 22-Dec-20 & 97.57 & 53.68 & 141.47 & & & & \\
\hline $23-$ Oct-20 & 86.91 & 72.02 & 101.79 & 23-Dec-20 & 97.75 & 53.29 & 142.21 & & & & \\
\hline $24-$ Oct-20 & 87.08 & 71.80 & 102.37 & 24-Dec-20 & 97.93 & 52.90 & 142.96 & & & & \\
\hline $25-$ Oct-20 & 87.26 & 71.58 & 102.94 & 25-Dec-20 & 98.11 & 52.51 & 143.71 & & & & \\
\hline $26-$ Oct-20 & 87.44 & 71.36 & 103.52 & 26-Dec-20 & 98.29 & 52.11 & 144.46 & & & & \\
\hline $27-$ Oct-20 & 87.62 & 71.13 & 104.10 & 27-Dec-20 & 98.46 & 51.72 & 145.21 & & & & \\
\hline 28 -Oct-20 & 87.80 & 70.90 & 104.69 & 28-Dec-20 & 98.64 & 51.32 & 145.96 & & & & \\
\hline $29-$ Oct-20 & 87.97 & 70.67 & 105.28 & 29-Dec-20 & 98.82 & 50.92 & 146.72 & & & & \\
\hline $30-$ Oct- 20 & 88.15 & 70.43 & 105.87 & $30-$ Dec-20 & 99.00 & 50.51 & 147.48 & & & & \\
\hline $31-$ Oct-20 & 88.33 & 70.19 & 106.47 & $31-$ Dec-20 & 99.17 & 50.11 & 148.24 & & & & \\
\hline
\end{tabular}

